ISSN 1392-3196 / e-ISSN 2335-8947

Zemdirbyste-Agriculture, vol. 102, No. 4 (2015), p. 431-436

DOI $10.13080 / \mathrm{z}-\mathrm{a} .2015 .102 .055$

\title{
GGE biplot analysis of genotype by environment interaction of spring barley varieties
}

\author{
Pavel SOLONECHNYI ${ }^{1}$, Nataliya VASKO ${ }^{1}$, Aleksey NAUMOV ${ }^{1}$, Olga SOLONECHNAYA ${ }^{1}$, \\ Olga VAZHENINA ${ }^{1}$, Olga BONDAREVA², Yuriy LOGVINENKO ${ }^{2}$
}

'Plant Production Institute nd. a V. Ya. Yuryev of NAAS

Moskovskiy 142, Kharkov, Ukraine

E-mail: pashabarley86@gmail.com

${ }^{2}$ Donetsk State Experimental Station of NAAS

Stadionna 15, v. Pisky, Yasynuvatskyy distr., Donetsk region, Ukraine

\begin{abstract}
The article presents results of genotype $(\mathrm{G})$ main effect and genotype by environment $(\mathrm{GE})$ interaction $(\mathrm{G} \times \mathrm{GE})$ biplot analysis of a multi environmental trial (MET) data in 17 varieties of spring barley conducted in 2013-2014. The objective of this study was to determine the effects of genotype, environment and their interaction on grain yield and to identify stable spring barley genotypes. The experimental layout was a randomized complete block design with three replications in each environment. Combined ANOVA indicated that the main effects due to environments, genotypes and genotype by environment interaction were highly significant. The contribution of environment, genotype and genotype by environment interaction to the total variation in grain yield was about $88.05,3.61$ and $7.54 \%$, respectively. The $\mathrm{G} \times \mathrm{GE}$ effects were further partitioned using a GGE biplot model. The first two principal components obtained by singular value decomposition of the centred data of yield accounted for $88.50 \%$ of the total variability caused by $\mathrm{G} \times \mathrm{GE}$. Out of these variations, PC1 and PC2 accounted for $51.38 \%$ and $37.12 \%$ of variability, respectively. The first mega-environment contains environments E1, E3 and E4 with variety 'Donetskyy 15 ' producing the highest yield; the second mega-environment only contains environment E2 with variety "Vzirets' being the most yielding. According to the biplot analysis of the "ideal" environment, it was concluded that E1 was the closest to the "ideal" environment and, therefore, the most desirable of all the test environments. GGE biplot view of this study identified the most productive and stable varieties - 'Donetskyy 14', 'Kosar' and 'Alegro'. Variety 'Stepovyk' is noticeable for its maximum fidelity to the "ideal”' genotype in terms of performance and stability.
\end{abstract}

Key words: GGE (genotype plus genotype by environment interaction) biplot, Hordeum vulgare, multi environment trials, yield.

\section{Introduction}

Ukraine is a leading exporter of barley grain in the world, but considerable year-to-year variations in barley grain production, which, in the first place, are due to significant susceptibility of modern varieties to environmental factors, are an essential challenge on the way to improving the country's positions in the global market.

The yield of each variety in any environment is a sum of environment $(E)$ main effect, genotype $(G)$ main effect and genotype by environment interaction (GE or GEI) (Farshadfar et al., 2013; Pourdad, Moghaddam, 2013). Farmers need varieties that show high performance in terms of yield and other essential agronomic traits. Their superiority should be reliable over a wide range of environmental conditions and years. The basic cause of difference in the performance of genotypes over environments is the occurrence of genotype by environment interaction (Gedif, Yigzaw, 2014). In barley breeding and in many aspects of barley research, the analysis of genotype by environment interactions is of primary importance, as it is also for other crops (Rodriguez et al., 2007; Jalata, 2011; Farshadfar et al., 2012). The best tool for estimating $\mathrm{G}$ and GE effects is multi environment trials (METs). METs are an optimal method to select better genotypes for any specific environment and to identify genotypes that consistently realize their genetic potential in a wide range of environments.

Data from METs are usually quite large, and it is difficult to deduce general patterns of such data without graphical representation. Yan et al. (2000) developed the GGE biplot technique for graphical analysis of multi environment trial data. GGE biplot analysis considers that only the G and GE effects are relevant and that they need to be considered simultaneously when evaluating genotypes. The GGE biplot has therefore been used in crop variety trials to effectively identify the best- 
performing genotype across environments, to identify the best genotypes for mega-environment delineation, whereby specific genotypes can be recommended for specific mega-environments, and to evaluate the yield and stability of genotypes (Yan, Kang, 2003; Yan, Tinker, 2006). The relative versatility of the GGE biplot, especially in mega-environment analysis and genotype selection, is worth exploiting for selection of genotypes for specific environments. More importantly, breeders will be able to identify stable genotypes with relatively consistent performance across a range of environments (Mohammadi, Amri, 2013; Mohammadi et al., 2014; Soto-Cerda et al., 2014). Thus, the GGE biplot technique has become a powerful tool to estimate and visualize genotype by environment interaction, which is widely used by breeders and agronomists all over the world (Casanoves et al., 2005; Koutis et al., 2012; Hagos, Abay, 2013; Sagar et al., 2014; Agyeman et al., 2015).

The objectives of this study were assessment of variations in yield performance of spring barley varieties across environments based on the GGE biplot and identification of the most valuable genotypes.

\section{Materials and methods}

Plant material and study site. Seventeen spring barley varieties bred at the Plant Production Institute nd. a V. Ya. Yuryev of NAAS and Donetsk State Experimental Station of NAAS served as source material. To determine their adaptive potential, in 2013-2014 an environmental trial was carried out in two locations with different soil and climatic conditions: Plant Production Institute nd. a V. Ya. Yuryev of NAAS (forest-steppe zone, subzone of unstable precipitation) and Donetsk State Experimental Station of NAAS (steppe zone, northern subzone) (Table 1). The climate in the forest-steppe zone (subzone of unstable precipitation) is temperate continental; the average annual rainfall is $550-600 \mathrm{~mm}$; the mean air temperature is $-6.6--8^{\circ} \mathrm{C}$ and $+19.5-+21.5^{\circ} \mathrm{C}$ during winter and summer season, respectively. The hydrothermal coefficient is $1.0-1.5$, which is optimal for barley vegetation. Soils in the fields of the Institute of the Plant Production Institute, Kharkov are typical mediumhumic black-soil with a humus content of $4.1-5.3 \%$ and a humus horizon thickness of $0.6-0.8 \mathrm{~m}$. The climate in the steppe zone (northern subzone) is temperate continental; the average annual rainfall is $425-450 \mathrm{~mm}$; the mean air temperature is $-6.0--7.5^{\circ} \mathrm{C}$ and $+21.5-+24.5^{\circ} \mathrm{C}$ during winter and summer season, respectively. The hydrothermal coefficient is $0.76-0.89$, which is below optimal for barley vegetation. Soils at Donetsk State Experimental Station, Yasynuvatskyy distr. are common low-humic black-earth (regraded) with the humus content of $4.0-4.6 \%$ and the humus horizon thickness of $0.45-0.7 \mathrm{~m}$.

The experimental layout was a randomized complete block design with three replications in each environment.

Table 1. Meteorological conditions during the spring barley growing season in two locations

\begin{tabular}{|c|c|c|c|c|c|c|c|c|}
\hline \multirow[b]{3}{*}{ Month } & \multicolumn{4}{|c|}{2013} & \multicolumn{4}{|c|}{2014} \\
\hline & \multicolumn{2}{|c|}{ Air temperature ${ }^{\circ} \mathrm{C}$} & \multicolumn{2}{|c|}{ Precipitation $\mathrm{mm}$} & \multicolumn{2}{|c|}{ Air temperature ${ }^{\circ} \mathrm{C}$} & \multicolumn{2}{|c|}{ Precipitation $\mathrm{mm}$} \\
\hline & $\begin{array}{l}\text { monthly } \\
\text { mean }\end{array}$ & $\begin{array}{l}\text { difference from } \\
\text { long-term mean }\end{array}$ & $\begin{array}{l}\text { monthly } \\
\text { mean }\end{array}$ & $\begin{array}{l}\text { difference } \\
\text { from long- } \\
\text { term mean }\end{array}$ & $\begin{array}{l}\text { monthly } \\
\text { mean }\end{array}$ & $\begin{array}{l}\text { difference } \\
\text { from long- } \\
\text { term mean }\end{array}$ & $\begin{array}{l}\text { monthly } \\
\text { mean }\end{array}$ & $\begin{array}{l}\text { difference } \\
\text { from long- } \\
\text { term mean }\end{array}$ \\
\hline & \multicolumn{8}{|c|}{ Plant Production Institute nd. a V.Ya. Yuryev } \\
\hline April & 11.3 & +1.7 & 7.6 & -27.9 & 9.5 & -0.1 & 39.0 & +3.5 \\
\hline May & 20.4 & +4.3 & 41.0 & -2.7 & 18.8 & +2.7 & 54.0 & +6.3 \\
\hline June & 22.2 & +2.0 & 38.0 & -25.3 & 18.5 & -1.7 & 138.0 & +74.7 \\
\hline \multirow[t]{2}{*}{ July } & 21.3 & -0.1 & 81.0 & +9.3 & 22.6 & +1.2 & 40.0 & -31.7 \\
\hline & \multicolumn{8}{|c|}{ Donetsk State Experimental Station } \\
\hline April & 11.3 & +2.4 & 23.3 & -15.7 & 10.4 & +1.5 & 27.0 & -12.0 \\
\hline May & 20.1 & +4.5 & 14.1 & -41.9 & 19.4 & +3.8 & 85.5 & +29.5 \\
\hline June & 22.1 & +2.8 & 96.0 & +40.0 & 19.9 & +0.6 & 95.5 & +39.5 \\
\hline July & 23.3 & +2.9 & 56.5 & +4.5 & 24.1 & +2.9 & 76.5 & +25.2 \\
\hline
\end{tabular}

Statistical analysis. The data obtained were analyzed using genotype and genotype by environment interaction (GGE) biplot. The model for the GGE biplot based on singular value decomposition (SVD) of first two principal components is:

$$
Y_{i j}-\mu-\beta_{j}=\lambda_{1} \xi_{i 1} \eta_{j 1}+\lambda_{2} \xi_{i 2} \eta_{j 2}+\varepsilon_{i j}
$$

where $Y_{i j}$ is the mean yield of genotype $i$ in environment $j, \mu$ - the grand mean, $\beta_{j}$ - the mean yield of all the genotypes in environment $j, \lambda_{1}$ and $\lambda_{2}-$ the singular values (SVs) of the $1^{\text {st }}$ and $2^{\text {nd }}$ principal components (PC1 and PC2), $\xi_{i 1}$ and $\xi_{i 2}$ - the eigenvectors of genotype $i$ for $\mathrm{PCl}$ and $\mathrm{PC} 2$, respectively, $\eta_{j 1}$ and $\eta_{j 2}$ - the eigenvectors of environment $j$ for $\mathrm{PCl}$ and $\mathrm{PC} 2$, respectively, $\varepsilon_{i j}$ - the residual associated with genotype $i$ in environment $j$.
To generate a biplot that can be used in visual analysis of multi environmental trial (MET) data, the singular values have to be partitioned into the genotype and environment eigenvectors so that the above model can be written in the form of:

$$
Y_{i j}-\mu-\beta_{j}=g_{i 1} e_{1 j}+g_{i 2} e_{2 j}+\varepsilon_{i j}
$$

where $g_{i 1} e_{l j}$ and $g_{i 2} e_{2 j}$ are $\mathrm{PCl}$ and $\mathrm{PC} 2$ scores for genotype $i$ and environment $j$, respectively.

In a biplot, genotype $i$ is displayed as a point defined by all $g_{i}$ values, and environment $j$ is displayed as a point defined by all $e_{j}$ values.

All biplots presented in this paper were generated using the software Genstat, version 17. 


\section{Results and discussion}

The yield capacity of the varieties varied both across environmental conditions, suggesting influence of the environmental factor "genotype-environment", and between genotypes within each environment, demonstrating genotypic dependence (Table 2).

The analysis of variance showed that the effects of genotype $(\mathrm{G})$, environment (E) and their interaction $(G \times E)$ on grain yield were statistically significant

Table 2. Grain yield capacity of spring barley varieties in the multi environment trial, $\mathrm{t} \mathrm{ha}^{-1}$

\begin{tabular}{|c|c|c|c|c|c|c|}
\hline \multirow{2}{*}{ Variety code } & \multirow{2}{*}{ Variety } & \multicolumn{2}{|c|}{$\begin{array}{c}\text { Plant Production Institute } \\
\text { nd. a V. Ya. Yuryev }\end{array}$} & \multicolumn{2}{|c|}{$\begin{array}{c}\text { Donetsk State } \\
\text { Experimental Station }\end{array}$} & \multirow{2}{*}{ Mean } \\
\hline & & $2013(\mathrm{E} 1)$ & $2014(\mathrm{E} 2)$ & $2013(\mathrm{E} 3)$ & $2014(\mathrm{E} 4)$ & \\
\hline G1 & Vzirets & 2.66 & 7.03 & 2.91 & 3.04 & 3.91 \\
\hline $\mathrm{G} 2$ & Agrariy & 2.55 & 6.18 & 3.25 & 2.97 & 3.74 \\
\hline G3 & Alegro & 3.00 & 6.62 & 3.33 & 3.05 & 4.00 \\
\hline G4 & Vektor & 3.55 & 6.06 & 3.05 & 2.77 & 3.86 \\
\hline G5 & Vitrazh & 3.33 & 5.82 & 3.06 & 2.78 & 3.75 \\
\hline G6 & Dokaz & 2.35 & 6.56 & 2.97 & 2.73 & 3.65 \\
\hline G7 & Donetskyy 14 & 3.82 & 5.55 & 3.60 & 3.12 & 4.02 \\
\hline G8 & Donetskyy 15 & 3.97 & 5.62 & 3.47 & 2.96 & 4.01 \\
\hline G9 & Etyket & 2.31 & 4.78 & 2.67 & 2.70 & 3.12 \\
\hline G10 & Zdobutok & 2.46 & 4.55 & 2.89 & 2.86 & 3.19 \\
\hline G11 & Inklyuziv & 3.06 & 6.77 & 2.38 & 2.97 & 3.80 \\
\hline G12 & Kozvan & 3.35 & 6.46 & 3.20 & 2.92 & 3.98 \\
\hline G13 & Kosar & 2.44 & 6.13 & 3.40 & 3.12 & 3.77 \\
\hline G14 & Modern & 3.30 & 5.83 & 3.22 & 2.94 & 3.82 \\
\hline G15 & Partner & 3.30 & 5.81 & 3.66 & 2.81 & 3.90 \\
\hline G16 & Stepovyk & 3.37 & 5.92 & 3.66 & 3.19 & 4.04 \\
\hline G17 & Skhidnyy & 3.42 & 5.41 & 3.26 & 3.12 & 3.80 \\
\hline \multicolumn{2}{|c|}{ Mean } & 3.07 & 5.95 & 3.18 & 2.94 & 3.78 \\
\hline
\end{tabular}

$(P \leq 0.01)$ (Table 3$)$. The $A N O V A$ for grain yield revealed that environment, genotype, and GE interaction effects accounted for $88.05,3.61$ and $7.54 \%$ of the total sum of squares, respectively. The E portion in METs is known to be the largest among all sources of variation, but it is regarded as irrelevant for genotype evaluation (Yan, Kang, 2003). This is the reason that $E$ is removed from the phenotypic data observed, which helps concentrate on $\mathrm{G}$ and $\mathrm{GE}$ effects, which are relevant for genotype evaluation (Yan, Kang, 2003; Fan et al., 2007).

Table 3. Analysis of variance for effects of genotype, environment and their interaction on spring barley grain yield in 2013-2014

\begin{tabular}{ccccc}
\hline Source & Sum of squares & Degree of freedom & Mean square & $\%$ SST \\
\hline Genotype $(\mathrm{G})$ & 13.219 & 16 & $0.826^{* *}$ & $107.444^{* *}$ \\
Environment $(\mathrm{E})$ & 322.332 & 3 & $0.575^{* *}$ & 88.05 \\
$\mathrm{G} \times \mathrm{E}$ & 27.594 & 48 & 0.021 & 7.54 \\
Error & 2.915 & 136 & & \\
Total & 366.06 & 203 & & \\
\hline
\end{tabular}

$\% \mathrm{SST}$ - percentage relative to the sum of squares total; ** - significant at the $1 \%$ level of probability

The GGE biplot was constructed using the first two principal components (PC1 and $\mathrm{PC} 2$ ) derived from subjecting the data to singular-value decomposition. The GGE biplot graphically displays G plus GE of the MET data in a way that facilitates visual variety evaluation and mega-environment identification (Yan, 2002; Yan et al., 2007; Yan, 2014). Only two PC (PC1 and PC2) are retained in the model because such a model tends to be the best model for extracting patterns. Via this model, PC1 and $\mathrm{PC} 2$ can be readily displayed in a two dimensional biplot so that the interaction between each genotype and each environment can be visualized.

The first two principal components obtained by singular value decomposition of the centred data of grain yield accounted for $88.50 \%$ of the total variability caused by $\mathrm{G}+\mathrm{GE}$. Out of these variations, $\mathrm{PC} 1$ and $\mathrm{PC} 2$ accounted for $51.38 \%$ and $37.12 \%$ of variability, respectively.
The GGE biplot analysis was used for estimation of discriminating power and representativeness of an environment as a test one for assessing genotypes. GGE biplot allows visualizing environment vectors lengths, which are proportional to standard deviations of genotype yields in a corresponding environment (Fig. 1). If the marker of a test environment is close to the biplot centre, i.e. has a short vector, all genotypes in it are similar, and this environment is not informative about their differentiation. Thus, environments E1 and E2 with long vectors had a high discriminating power, and environment E4 was characterized by a low discriminating power.

The cosine of the angle between environment vectors is used for assessment of approximation between them: the smaller the angle between environment vectors is the larger correlation between them is (Yan, Holland, 2010). Correspondingly, there is a strong correlation between environments $\mathrm{E} 1$ and $\mathrm{E} 3$. 


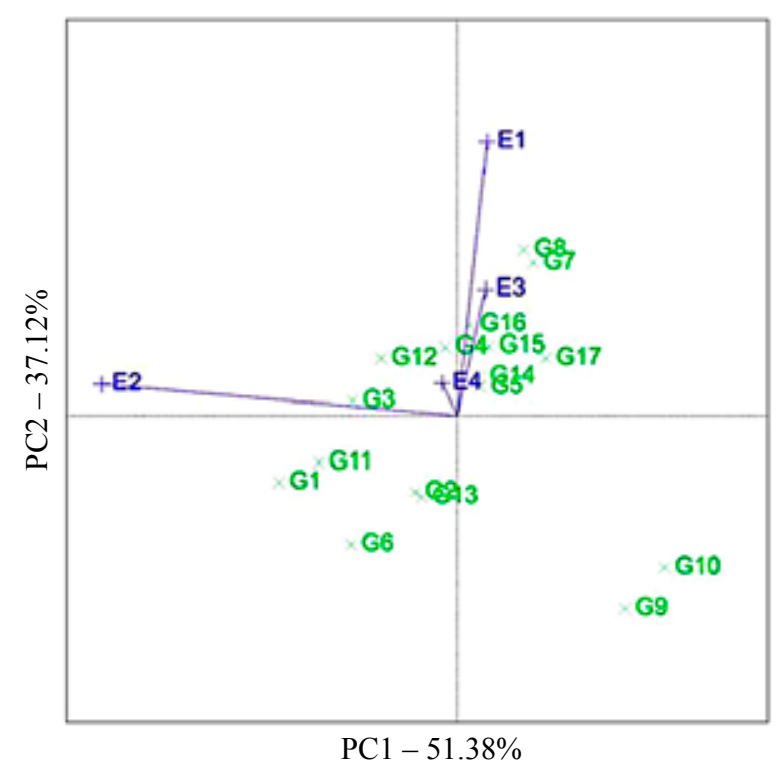

Figure 1. The environment-vector view of the GGE (genotype plus genotype by environment interaction) biplot to show similarities among the test environments in discriminating the genotypes

The GGE biplot way of measuring representativeness of environments is to define an average environment and use it as a reference for comparison. A test environment with a small angle to average environment coordinate (AEC) is the most representative related to the other test environments. The "ideal" environment (indicated by circle with an arrow pointing into it in Figure 2) is the most discriminating of genotypes and yet representative of the other test environments. Thus, in our studies environment E1 was the most desirable for estimating genotypes.

The "which-won-where" polygon view of a GGE biplot is an effective way to visualize the interaction patterns between genotype and environment (Fig. 3). The polygon vertices are genotype markers that are maximally remote from the biplot centre. The lines dividing the biplot

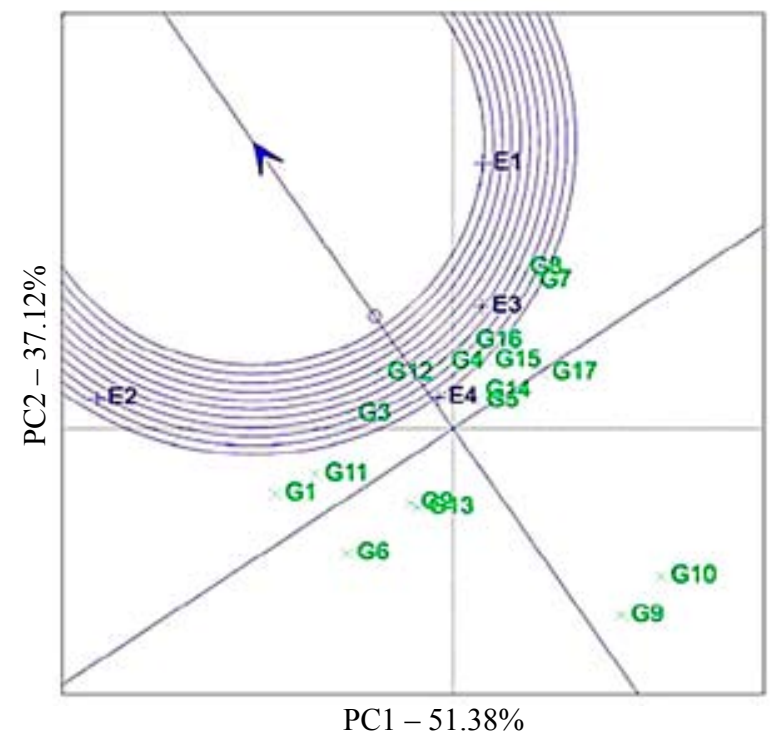

Figure 2. Ranking of environments based on discriminating ability and representativeness into sectors represent a set of hypothetical environments. If a genotype at an angular vertex of the polygon falls within one sector with an environment marker (or with several markers), that means that the yield capacity of this genotype was the highest in this particular environment. Another important feature of this biplot is that it indicates environmental groupings, which suggests the possible existence of different mega-environments. Thus, in our studies the first mega-environment consists of environments E1, E3 and E4 with variety 'Donetskyy 15' (G8) producing the highest yield. The environment E2 makes up another mega-environment, where variety 'Vzirets' (G1) is the most yielding.

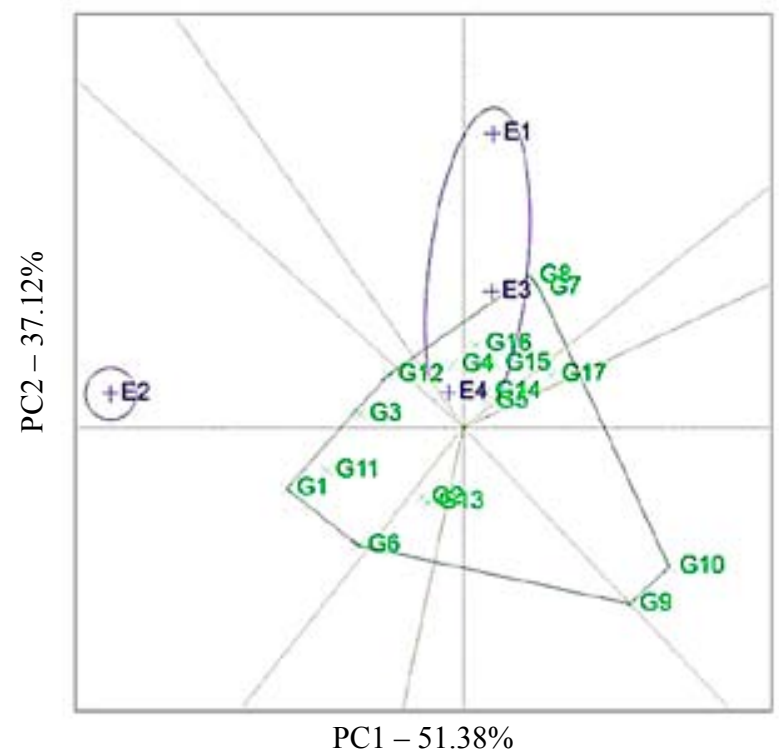

Figure 3. Polygon view of GGE (genotype plus genotype by environment interaction) biplot for the "which-wonwhere" pattern of genotypes and environments

The GGE biplot ranks genotypes by their mean yield capacity and stability in a number of environments (Fig. 4). The average tester coordinates (ATC) $\mathrm{x}$-axis or the performance line passes through the biplot origin with an arrow indicating the positive end of the axis and ranks genotypes according to their performance. The ATC y-axis or the stability axis passes through the biplot origin is perpendicular to the ATC $\mathrm{x}$-axis. The mean yield capacity of genotypes is estimated by the projections of their markers to the ATC x-axis. Varieties 'Stepovyk' (G16) and 'Donetskyy 14' (G7) had the highest mean yield, and variety 'Etyket' (G9) - the lowest mean yield. The yields in varieties 'Inklyuziv' (G11) and 'Vzirets' (G1) had the most variable, while varieties 'Modern' (G14), 'Vektor' (G4) and 'Kozvan' (G12) were noticeable for their high stability.

An "ideal" genotype is one that has both high mean yield capacity and high stability. The centre of concentric circles (Fig. 5) represents the position of an "ideal" genotype, which is defined by a projection onto the mean-environment axis that equals the longest vector of the genotypes that had above-average mean yields and by a zero projection onto the perpendicular line (zero variability across all environments). The closer a genotype to the ideal one is the more valuable it is. Although such an "ideal" genotype may not exist in reality, it can be used as a reference for genotype evaluation (Yan, Tinker, 2006). 


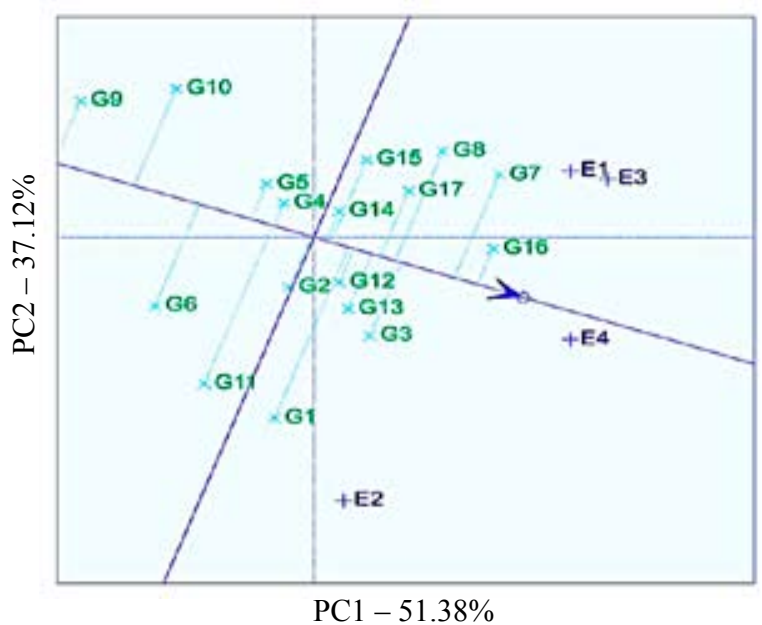

Figure 4. Average environment coordination (AEC) views of the GGE (genotype plus genotype by environment interaction)-biplot based on environment-focused scaling for the means of performance and stability of genotypes

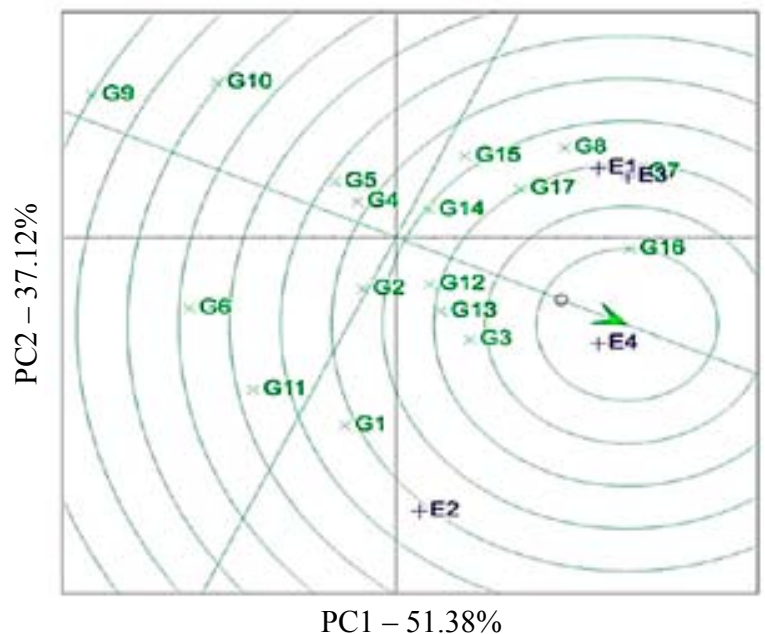

Figure 5. The average environment coordination (AEC) view to rank genotypes relative to an "ideal" genotype (the centre of the concentric circles)

The ranking based on the genotype-focused scaling assumes that stability and mean yield are equally important. Thus, variety 'Stepovyk' (G16), which is close to the centre of concentric circles, was an "ideal" genotype in terms of yield capacity and stability compared with the other genotypes. Varieties 'Donetskyy 14' (G7), 'Kosar' (G13) and 'Alegro' (G3) located in the next concentric circle are also regarded as valuable genotypes in terms of yield capacity and stability.

\section{Conclusions}

1. The study revealed that spring barley yield was highly influenced by variable cultivation environments followed by the differences among genotypic effects, and genotype by environment interaction $(\mathrm{G} \times \mathrm{E})$ contributing the least. This study also clearly demonstrated that the GGE biplot model was effective for the determination of the magnitude and pattern of $\mathrm{G} \times \mathrm{E}$ effect and visualizing the yield potential and stability of spring barley genotypes as well as discriminating ability and representativeness of the test environments.
2. The study results identified spring barley variety 'Stepovyk' as the closest to the "ideal" genotype in terms of yield potential and stability. Varieties 'Donetskyy 14', 'Kosar' and 'Alegro' were also selected as superior genotypes

Received 18052015

Accepted 28082015

\section{References}

Agyeman A., Parkes E., Peprah B. B. 2015. AMMI and GGE biplot analysis of root yield performance of cassava genotypes in the forest and coastal ecologies. International Journal of Agricultural Policy and Research, 3 (3): 222-232 http://dx.doi.org/10.15739/IJAPR.034

Casanoves F., Baldessari J., Balzarini M. 2005. Evaluation of multi-environment trials of peanut cultivars. Crop Science, 45: $18-26$ http://dx.doi.org/10.2135/cropsci2005.0018

Fan X. M., Kang M. S., Chen H., Zhang Y., Tan J., Xu C. 2007. Yield stability of maize hybrids evaluated in multienvironment trials in Yunnan, China. Agronomy Journal, 99: $220-228$ http://dx.doi.org/10.2134/agronj2006.0144

Farshadfar E., Mohammadi R., Aghaee M., Vaisi Z. 2012. GGE biplot analysis of genotype $\times$ environment interaction in wheat-barley disomic addition lines. Australian Journal of Crop Science, 6 (6): 1074-1079

Farshadfar E., Rashidi M., Jowkar M. M., Zali H. 2013. GGE biplot analysis of genotype $\times$ environment interaction in chickpea genotypes. European Journal of Experimental Biology, 3 (1): 417-423

Gedif M., Yigzaw D. 2014. Genotype by environment interaction analysis for tuber yield of potato (Solanum tuberosum L.) using a GGE biplot method in Amhara Region, Ethiopia. Agricultural Sciences, 5: 239-249 http://dx.doi.org/10.4236/as.2014.54027

Hagos H. G., Abay F. 2013. AMMI and GGE biplot analysis of bread wheat genotypes in the Northern part of Ethiopia. Journal of Plant Breeding and Genetics, 1 (1): 12-18

Jalata Z. 2011. GGE-biplot analysis of multi-environment yield trials of barley (Hordeum vulgare L.) genotypes in Southeastern Ethiopia highlands. International Journal of Plant Breeding and Genetics, 5 (1): 59-75 http://dx.doi.org/10.3923/ijpbg.2011.59.75

Koutis K., Mavromatis A. G., Baxevanos D., KoutsikaSotiriou M. 2012. Multi environmental evaluation of wheat landraces by GGE biplot analysis for organic breeding. Agricultural Sciences, 3: 66-74 http://dx.doi.org/10.4236/as.2012.31009

Mohammadi R., Amri A. 2013. Genotype $\times$ environment interaction and genetic improvement for yield and yield stability of rainfed durum wheat in Iran. Euphytica, 192: 227-249 http://dx.doi.org/10.1007/s10681-012-0839-1

Mohammadi R., Haghparast R., Sadeghzadeh B., Ahmadi H., Solimani K., Amri A. 2014. Adaptation patterns and yield stability of durum wheat landraces to highland cold rainfed areas of Iran. Crop Science, 3 (1): 944-954 http://dx.doi.org/10.2135/cropsci2013.05.0343

Pourdad S. S., Moghaddam M. J. 2013. Study on seed yield stability of sunflower inbred lines through GGE biplot. Helia, 36 (58): 19-28 http://dx.doi.org/10.2298/HEL1358019P

Rodriguez M., Rau D., Papa R., Attene G. 2007. Genotype by environment interactions in barley (Hordeum vulgare L.): different responses of landraces, recombinant inbred lines and varieties to Mediterranean environment. Euphytica, 163: 231-247 htttp://dx.doi.org/10.1007/s10681-007-9635-8 
Sagar V., Yadav R., Jain N., Gaikwad K. B., Prabhu K. V. 2014. Consolidating the yield gain by exploiting genotype $\times$ management interaction in wheat. Indian Journal of Genetics and Plant Breeding, 74 (2): 157-165 http://dx.doi.org/10.5958/0975-6906.2014.00151.5

Soto-Cerda B. J., Westermeyer F., Iniguez-Luy F., Munoz G., Montenegro A., Cloutier S. 2014. Assessing the agronomic potential of linseed genotypes by multivariate analyses and association mapping of agronomic traits. Euphytica, 196: 35-49 http://dx.doi.org/10.1007/s10681-013-1012-1

Yan W. 2002. Singular-value partitioning in biplot analysis of multi-environment trial data. Agronomy Journal, 94: 990-996 http://dx.doi.org/10.2134/agronj2002.0990

Yan W. 2014. Crop variety trials: data management and analysis, $360 \mathrm{p}$.

http://dx.doi.org/10.1002/9781118688571
Yan W., Kang M. S. 2003. GGE biplot analysis: a graphical tool for breeders, geneticists and agronomists, $271 \mathrm{p}$.

Yan W., Tinker N. A. 2006. Biplot analysis of multi-environment trial data: principles and applications. Canadian Journal of Plant Science, 86: 623-645 http://dx.doi.org/10.4141/P05-169

Yan W., Holland J. B. 2010. A heritability-adjusted GGE biplot for test environment evaluation. Euphytica, 171: 355-369 http://dx.doi.org/10.1007/s10681-009-0030-5

Yan W., Hunt L. A., Sheny Q., Szlavnics Z. 2000. Cultivar evaluation and mega-environment investigation based on the GGE biplot. Crop Science, 40: 597-605 http://dx.doi.org/10.2135/cropsci2000.403597x

Yan W., Kang M. S., Ma B., Woods S., Cornelius P. L. 2007. GGE biplot vs. AMMI analysis of genotype-byenvironment data. Crop Science, 47: 643-655 http://dx.doi.org/10.2135/cropsci2006.06.0374

ISSN 1392-3196 / e-ISSN 2335-8947

Zemdirbyste-Agriculture, vol. 102, No. 4 (2015), p. 431-436

DOI $10.13080 /$ z-a.2015.102.055

\title{
Vasarinio miežio veislių genotipo ir aplinkos sąveika taikant GGE biplot analizę
}

\author{
P. Solonechnyi ${ }^{1}$, N. Vasko ${ }^{1}$, A. Naumov ${ }^{1}$, O. Solonechnaya ${ }^{1}$, O. Vazhenina ${ }^{1}$, O. Bondareva ${ }^{2}$, \\ Y. Logvinenko ${ }^{2}$ \\ ${ }^{1}$ Charkovo augalininkystės institutas, Ukraina \\ ${ }^{2}$ Donetsko valstybinè bandymų stotis, Ukraina
}

\section{Santrauka}

Straipsnyje pateikti genotipo $(\mathrm{G})$ pagrindinès įtakos ir genotipo bei aplinkos $(\mathrm{GE})$ sąveikos $(\mathrm{G} \times \mathrm{GE})$ biplot analizès, atliktos naudojant daugybinès aplinkos bandymų duomenis, rezultatai. Ši analizè buvo atlikta 17-ai vasarinio miežio veislių 2013-2014 m. Tyrimo tikslas - nustatyti genotipo bei aplinkos įtaką ir jų sąveiką grūdų derliui ir stabilius vasarinio miežio genotipus. Buvo taikyta randomizuoto bloko schema su trimis pakartojimais kiekvienoje aplinkoje. Sudetinè dispersinè ANOVA analizė parodè, kad aplinkos, genotipų ir genotipo bei aplinkos sąveikos įtaka buvo esminè. Aplinkos, genotipo ir genotipo bei aplinkos sąveikos įtaka bendrai grūdų derliaus variacijai buvo atitinkamai $88,05,3,61$ ir 7,54 \%. G $\times$ GE ịtaka toliau buvo analizuota taikant GGE biplot modeli. Pirmieji du principiniai komponentai sudare $88,50 \%$ bendros derliaus variacijos, nulemtos $\mathrm{G} \times \mathrm{GE}$. Iš ju PC1 ir PC2 paaiškino atitinkamai 51,38 ir 37,12 \% variantiškumo. Pirmoji megaaplinka apèmè E1, E3 ir E4 aplinkas, kuriose derlingiausia yra veislè 'Donetskyy 15'; antrają megaaplinką sudare tik E2 aplinka, kurioje derlingiausia yra veislė 'Vzirets'. Pagal ,idealios“ aplinkos biplot analizę buvo padaryta išvada, kad E1 aplinka artima idealiai ir todèl yra labiausiai pageidautina iš visų aplinkų. GGE biplot analizè nustatè pačias derlingiausias ir stabiliausias veisles - 'Donetskyy 14', 'Kosar' ir 'Alegro'. Pagal tyrimo rezultatus ir stabilumą maksimaliu atitikimu idealiam genotipui išsiskyrè veislè 'Stepovyk'.

Reikšminiai žodžiais: bandymai, atlikti daugybinèje aplinkoje, derlius, GGE (genotipo ir genotipo bei aplinkos sąveika) biplot, Hordeum vulgare. 